\title{
Effect of non-suckling on the pH of breast milk and its possible relationship with breast cancer
}

\author{
S. L. MALHOTRA* \\ F.R.C.P. \\ Department of Family and Community Medicine, University of Garyounis, Benghazi, Libya
}

\begin{abstract}
Summary
The pH of breast milk was determined in 10 lactating mothers after interrupting suckling from one of the breasts, alternately for $120 \mathrm{hr}$ during the 1st, 12th and the 16th postpartum weeks. The milk from the unsuckled breasts had a slightly higher $\mathrm{pH}$ at all three times, being slightly alkaline as compared with the suckled breasts from which the milk was slightly acidic. There were differences also between the three diurnal feeds, the $\mathrm{pH}$ being higher in the last diurnal samples. If this temporary experimental stoppage of breast feeding is akin to decline of breast feeding, the changes in the pH of breast milk caused by it may provide clues to the mechanism of the long-suggested possible carcinogenic effect of a fall in the prevalence of breast feeding. An alkaline milieu surrounding epithelial cells causes hyperplasia, cell atypia and a marked increase in mitotic activity, changes which are a prelude to neoplasia. The causative relationship of late age at first birth does not find support in the thesis of the alkaline milieu in the aetiology of breast cancer presented here.
\end{abstract}

\section{Introduction}

It has been suggested that an alkaline milieu surrounding epithelial cells plays an important role in carcinogenesis of epithelial surfaces (Malhotra, 1967, 1970, 1976, 1977a,b). Although the longsuggested influence of lactation and breast feeding has been questioned by some workers, notably MacMahon and his group (MacMahon et al., 1970 a,b; Yuasa and MacMahon, 1970; Lowe and MacMahon, 1970), it seemed relevant to compare the $\mathrm{pH}$ of breast milk from the suckled and the unsuckled breast in view of the differences between the two, noted in an earlier study (Malhotra, 1977a).

In the present study the $\mathrm{pH}$ of breast milk in 10 lactating mothers was measured during the first,

\footnotetext{
*Present address: via del corso 24, 00186 Roma, Italy.
}

twelfth and the sixteenth week after delivery, after stopping suckling for $120 \mathrm{hr}$ from one of the breasts.

Subjects and methods

\section{Subjects}

On the sixth postpartum day, 10 co-operative lactating mothers randomly selected from the maternity wards, with normal full-term deliveries, were randomly placed in two groups of five each. Neither the mothers nor their infants were taking any medicines, and were well.

The mothers in one group were instructed not to suckle their babies from the left breast for $120 \mathrm{hr}$; and the other group from the right breast. At the end of the experimental period of $120 \mathrm{hr}, 5 \mathrm{ml}$ of breast milk were extracted from each breast separately with an Egnell breast pump. The sequence of laterality of the breasts was then reversed and at the end of the next $120 \mathrm{hr} 5 \mathrm{ml}$ of breast milk were similarly extracted separately from each breast. Samples were taken at the three diurnal feeds since two pilot studies had shown that the differenees between the $\mathrm{pH}$ of the milk from the suckled as compared with the unsuckled breast tended to be greater towards the later diurnal feeds. The experimental procedure was repeated in the 12th and 16th postpartum weeks.

\section{Methods}

The $\mathrm{pH}$ of the breast milk samples was determined immediately after collection with the Beckman pH meter using glass electrodes.

\section{Results}

Three mothers were excluded from study in the first week due to the need to suckle, or extrusion of milk from both breasts. All the mothers, however, cooperated during the remaining two periods, i.e. the 12th and 16th weeks. 


\section{Mean $p H$ of breast milk in $p H$ units}

The mean $\mathrm{pH}$ values for the breast milk from the unsuckled breasts were significantly higher (analysis of variance) as compared with the milk from the suckled breasts in all the three periods (Table 1). The differences between the mean values of the two types of milk were $0.93,0.75$ and 1.04 during the 1st, the 12 th and the 16th week respectively.

TABLE 1. Mean $\mathrm{pH}$ of milk from the suckled and unsuckled breasts in 10 lactating mothers during the 1st, 12th and the 16th week after delivery (six milk samples from each mother at each time)

\begin{tabular}{lccccc}
\hline & \multicolumn{2}{c}{$\begin{array}{c}\text { Suckled } \\
\text { Time }\end{array}$} & \multicolumn{2}{c}{ Unsuckled } & \\
interval & Mreasts & \multicolumn{2}{c}{ breasts } & $P$ \\
& & \pm s.d. & Mean & \pm s.d. & value \\
\hline 1st week $(n=42)^{*}$ & 6.88 & 0.91 & 7.81 & 1.0 & $<0.01$ \\
12th week $(n=60)$ & 7.15 & 1.12 & 7.90 & 1.14 & $<0.02$ \\
16th week $(n=60)$ & 6.71 & 1.2 & 7.75 & 1.4 & $<0.01$ \\
\hline
\end{tabular}

*Results from only seven mothers in the first week.

\section{Distribution of samples of milk in different $p H$ ranges}

There were more samples in the higher $\mathrm{pH}$ ranges (pH $>7 \cdot 4$, alkaline reaction) and fewer in the lower $\mathrm{pH}$ ranges ( $\mathrm{pH}<7.4$, acidic reaction) in the unsuckled breast as compared with the samples from the suckled breast for all the three periods combined (Table 2$)$. This was highly significant $\left(P<0.001, X^{2}\right.$ test).

\section{Validity of the results}

Three diurnal samples were taken as it was seen in the pilot studies that the differences between the $\mathrm{pH}$ of milk from the suckled as compared with the unsuckled breasts were greater towards the later parts of the day. This is also seen in the present study (Table 3). The reasons for this are totally unclear and its significance not known.

\section{Discussion}

The mechanism by which the pH of breast milk undergoes a shift towards alkalinity if the breast is not suckled during lactation is unclear. During normal lactation and breast-feeding, the breast milk is slightly acidic with a $\mathrm{pH}$ range of 6.88 to $7 \cdot 15$.

This loss of acidity is nevertheless relevant because
TABLE 3. Comparison of the pH of breast milk samples between the three diurnal feeding schedules: 6 a.m., 10 a.m. and 6 p.m., in ten lactating mothers

\begin{tabular}{rcccccc}
\hline & \multicolumn{4}{c}{ Suckled } & \multicolumn{2}{c}{ Unsuckled } \\
breast \\
& $(n)$ & Mean & \pm s.d. & Mean & \pm s.d. & $P$ value \\
\hline 6 a.m. & 54 & 7.12 & 0.84 & 7.75 & 0.91 & $<0.02$ \\
10 a.m. & 54 & 6.75 & 0.98 & 7.84 & 0.89 & $<0.001$ \\
6 p.m. & 54 & 6.76 & 0.81 & 7.9 & 1.0 & $<0.001$ \\
\hline
\end{tabular}

in an alkaline milieu, epithelial cells are damaged (James, 1957; Ball and James, 1961). As a result of this the cell undergoes hyperplasia, marked cell atypia and a striking 40-fold increase in mitotic activity in gastric mucosa (Lawson, 1964; du Plessis, 1965). Dunham, Muir and Hamner (1966) produced similar changes in hamster cheek pouches by repeatedly painting with an alkaline solution of calcium hydroxide. Dunham, Sheets and Morton (1974) induced similar changes leading to carcinoma insitu in hamster cheek pouches and oesophagus by treating them with quids of plant extracts, such as arecoline and calcium hydroxide. Arecoline alone failed to produce any lesions. Shanta and Krishnamurthi (1963), Hirayama (1966) and Malhotra (1967) suggested that it was the alkaline slaked lime and not tobacco in the betel leaf quid which was responsible for such changes leading to cancers of the buccal cavity and the oesophagus. There is also evidence which shows that cancer of the cervix uterii may also be produced by a similar mechanism of the interaction between an alkaline seminal fluid and the epithelial cells of the portio of the cervix. Seminal fluid is rendered alkaline by frequent sexual intercourse (Malhotra, 1971). Cancer of the colon also appears to be due to a similar mechanism of increased alkalinity (Malhotra, 1967, 1977b, 1981, 1982a,b; Thornton, 1981). The thesis of the alkaline milieu (Malhotra, 1976) can also explain why cancer of the lung is more common in sufferers of chronic bronchitis where the ciliated respiratory epithelium changes into goblet cells. On coming into contact with cigarette smoke, which is alkaline (Malhotra, 1970), these cells undergo similar changes of marked hyperplasia, cell atypia and an increase in mitotic activity. Such pre-cancerous changes have been noted in smokers' lungs. Hyperplasia is a prelude to neoplasia (Poel, 1964).

Breast feeding and high parity have long been

TABLE 2. Distribution of 162 milk samples in different $\mathrm{pH}$ ranges

\begin{tabular}{lcccccccc}
\hline pH & $5 \cdot 6-6.0$ & $6 \cdot 1-6.5$ & $6 \cdot 6-7 \cdot 0$ & $7 \cdot 1-7 \cdot 5$ & $7 \cdot 6-8.0$ & $8 \cdot 1-8.5$ & 8.6 & Total \\
\hline Suckled breast & 9 & 12 & 35 & 9 & 15 & 1 & 0 & 81 \\
Unsuckled breast & 0 & 4 & 8 & 23 & 24 & 11 & 11 & 81 \\
\hline
\end{tabular}


considered as protective against cancer of the breast (Lane-Claypon, 1926; Bagg, 1925; Wainright, 1931; Khanolkar, 1967; Haagesen, 1971). Contrary to this are the findings of MacMahon and his colleagues (MacMahon et al., 1970a; MacMahon et al., 1970b; Yuasa and MacMahon, 1971; Lin, Chen and MacMahon, 1971; Mirra, Cole and MacMahon, 1971). These authors have considered late age at first birth to be the dominant risk factor and excluded decline of breast feeding as a cause (Yuasa and MacMahon, 1970). But recent studies from Sweden (Adami et al., 1978), Canada (Choi et al., 1978), Burma (TheinHlang and Thein-Maung-Myint, 1978), Iceland (Tulinius et al., 1978) and from Maryland (Craig, Comstock and Leiser, 1974) are in conflict with the findings of MacMahon and his colleagues regarding the role of age at first birth specifically. These studies found no relationship whatever between age at first birth and the risk of developing cancer of the breast. The reasons for these contradictory findings and interpretations are not readily clear and caution is necessary in this particular area of breast cancer research.

Some recent studies from Arab Countries-Sudan (Daud et al., 1965), Saudi Arabia (Sterling and Alfadli, 1981), Uganda (Templeton, 1973) and Libya (Malhotra and Abudejaja, 1980) are also at variance with the suggestion that early age at first birth is protective. In these countries first birth in the teens is the rule rather than the exception, yet cancer of the breast is the second most common malignancy in women, after cancer of the cervix (Sterling and Alfadli, 1981). The frequency of these malignancies of the breast seem to be on the increase in these countries side by side with a continuous decline in breast feeding and a concomitant increase in bottle feeding (El Radhi, Wasti and Majeed, 1981; Abudejaja, Malhotra, Mehgoob and Khan, 1981, unpublished data).

Cole and MacMahon (1969) have postulated that the relative levels of individual oestrogen fractions produced in the first decade or so after puberty are important determinants of a women's life-time breast cancer risk. They suggest that the first pregnancy induces irreversible changes that either render the breast tissue itself less susceptible to induction of cancer, or reduce the carcinogenic stimulus to the breast (MacMahon et al., 1970a). Morgan et al. (1978) obtained contradictory results in oestrogen profiles in young women with a maternal breast cancer history. More studies on hormone profiles are urgently needed, especially from areas in the Arab world where age at first birth is low and yet breast cancer incidence is high. The hormone thesis, with which is linked the age at first birth, fails to explain many epidemiological features of cancer of the breast, among which is the universal observation of the striking preponderance of the involvement of the left breast (McManus, 1977).

On the other hand, the $\mathrm{pH}$ thesis explains all the known features of this disease including the striking preponderance of the involvement of the left breast in most published series. It has been noticed that this is predominantly so in the case of right-handed women. The few cases that we came across in whom the lesion started in the right breast were left-handed women. The reasons for this are not clear but two surveys showed that it was the practice among righthanded women to nurse their infants with the right breast before the left. This is likely to produce alkalinity of the breast milk in the left breast since this practice may result in partial non-suckling of the left breast. Highly conjectural but nevertheless probable, this needs further investigation since it is possible that the right-handed mothers would find it natural and convenient to support the heavier head end of the infant on their right arms.

In the present state of knowledge, a great deal of caution is necessary to separate the two current, contradictory and debatable views: (1) 'Evidence now has accumulated to the point where the lactation hypothesis may be discarded' (Vakil and Morgan, 1973); (2) 'I cannot ignore the basic truth that in ethnic groups breast feeding appears to protect against breast cancer, and I believe it is my duty as a physician to advise breast feeding and to do all I can to help women to succeed with it' (Haagesen, 1971).

\section{Acknowledgments}

I am grateful to Professor Giogio Dall'Aglio D.Sc.(Rome), M.I.S.I., U.M.I.(Rome), Chairman, Institute of Probability, Faculty of Statistics, University of Rome and to Dr Gianfranco Cavedon, L.Sc.(Statistics), Ricercatore, for their valuable help with the statistical analyses. To the lactating mothers who participated in the investigation, I owe a special debt of gratitude.

\section{References}

Adami, H.O., Rimsten, A., Stenkvist, B. \& Vegelius, J. (1978) Reproductive history and risk of breast cancer: A case-control study in an unselected Swedish population. Cancer (Philadelphia), 41, 747.

BAGG, H. (1925) The functional activity of the breast in relation to mammary carcinoma in mice. Proceedings of the Society for Experimental Biology and Medicine, 22, 419.

BALL, P.A.J. \& JAMES, A.H. (1961) The histological background to gastric ulcer. Lancet, i, 1365.

Chol, N.W., Howe, G.R., Miller, A.B., Mathews, V., Morgan, R.W., Munan, L., Burch, J.D., Feather, J., Jain, M. \& Kelly, A. (1978) An epidemiologic study of breast cancer. American Journal of Epidemiology, 107, 510.

Cole, P. \& MACMAHON, B. (1969) Oestrogen fractions during early reproductive life in the aetiology of breast cancer. Lancet, $\mathbf{i}, 604$.

Craig, T.J., Comstock, G.W. \& GeISer, P.B. (1974) Epidemiologic comparison of breast cancer patients with early and late onset of malignancy and general population controls. Journal of the National Cancer Institute, 53, 1577. 
DAUD, E.H., HASAN, A.M., ZAK, F. \& ZAKOVA, H. (1965) Aspects of malignant disease in Sudan. In: Cancer in Africa (Ed by Clifford, P., Linsell, C.A. \& Tims, G.L.), p. 43, East African Publishing House.

Dunham, L.J., MuIR, C.S. \& Hamner, III, J.E. (1966) Epithelial atypia in hamster cheek pouches treated repeatedly with calcium hydroxide. British Journal of Cancer, XX, 588.

Dunham, L.J., Sheets, R.H. \& Morton, J.F. (1974) Proliferative lesions in cheek pouches and esophagus of hamsters treated with plants from Curacao, Netherland Antilles. Journal of the National Cancer Institute, 53, 1259.

DU PLESSIS, D.J. (1965) Pathogenesis of gastric ulceration. Lancet, i, 974.

El Radhi, A.S., Wasfi, M.S. \& Majeed, M. (1981) Statistical evaluation of artificial feeding in Iraq. Saudi Medical Journal, 2, 203.

HAAGESEN, C.D. (1971) Diseases of the Breast. W. B. Saunders, Philadelphia.

HIRAYAMA, T. (1966) An epidemiological study of oral and pharyngeal cancers in central and Southeast Asia. Bulletin of the World Health Organisation, 34, 41.

James, A.H. (1957) The Physiology of Gastric Digestion, pp 128, 231. E. Arnold, London.

KHANOLKAR, V. (1967) Breast cancer in Bombay. International Union against Cancer, 6, 881.

LANE-CLAYPON, J.E. (1926) A further report on cancer of the breast with special reference to its associated antecedent conditions. Reports on Public Health and Medical Subjects, No. 32, Ministry of Health, London.

LAWSON, H.H. (1964) Effect of duodenal contents on the gastric mucosa under experimental conditions. Lancet, i, 469.

Lin, T.M., Chen, K.P. \& MacMahon, B. (1971) Epidemiological characteristics of breast cancer in Taiwan. Cancer (Philadelphia), $27,1497$.

Lowe, C.R. \& MACMAHON, B. (1970) Breast cancer and reproductive history of women in South Wales. Lancet, i, 153.

macmahon, B., Cole, P., Lin, T.M., Lowe, C.R., Mirra, A.P., Ravinhar, B., Salber, E.J., Valaoras, V.G. \& Yuasa, S. (1970a) Age at first birth and breast cancer risk. Bulletin of the World Health Organisation, 43, 209.

MacMahon, B., LiN, T.M., Lowe, C.R., MirRa, A.P., Ravnihar, B., Salber, E.J., Trichopoulos, D., Valaoras, V.G. \& Yuasa, S. (1970b) Lactation and cancer of the breast. A summary of an international study. Bulletin of the World Health Organisation, 42, 185.

McManus, J.C. (1977) Predominance of left-sided breast tumours Lancet, ii, 297.

MALHOTRA, S.L. (1967) Geographical distribution of gastrointestinal cancers in India with special reference to causation. Gut, 8, 361 .

MALhotRA, S.L. (1970) Clues to the possible mode of action of cigarette smoke in the pathogenesis of lung cancer. Journal of the Indian Medical Association, 8, 265.

MALHOTRA, S.L. (1971) A study of the carcinoma of uterine cervix with special reference to its causation and prevention. British Journal of Cancer, XXV, 62.
MALHOTRA, S.L. (1976) New approaches to the causation and prevention of cancers of epithelial surfaces. Medical Hypotheses, 2(6), 279.

MALHOTRA, S.L. (1977a) A study of cancer of breast with special reference to its causation and prevention. Medical Hypotheses, 3(1), 21.

MALHOTRA, S.L. (1977b) Dietary factors in a study of cancer colon from cancer registry with special reference to the role of saliva, milk and fermented milk products and vegetable fibre in the diet. Medical Hypotheses, 3(3), 122.

Malhotra, S.L. \& Abudejaja, A.H. (1980) Indo-Libyan experiences of breast-feeding practices and cancer breast. Garyounis Medical Journal, Special issue.

MALhOTRA, S.L. (1981) Cholecystectomy and carcinoma of the colon. Letter to Editor. Lancet, ii, 931.

Malhotra, S.L. (1982a) Faecal urobilinogen levels and the pH of stools in population groups with different cancer colon incidence and their possible role in the aetiology of cancer colon. Journal of the Royal Society of Medicine, 75, 709.

MALHOTRA, S.L. (1982b) Faecal urobilinogen levels and the $\mathrm{pH}$ of stools in cancer colon: a case-control study. Submitted for publication.

MALHOTRA, S.L. (1982c) Status of age at first birth as a cause of cancer breast: a case-control study. Submitted for publication.

MirRa, A.P., Cole, P. \& MACMAHON, B. (1971) Breast cancer in an area of high parity, Sao Paulo, Brazil. Cancer Research, 31, 77.

MoRGAN, R.W., VAKIL, D.V., BROWN, J.B. \& Eliason, L. (1978) Estrogen profiles in young women: Effect of maternal history of breast cancer. Journal of National Cancer Institute, 60, 965.

POEL, W.E. (1964) The cause and nature of cancer. In: Progress in Experimental Tumour Research, vol 5, p. 5 (Ed by Homburger, B.). Karger, Basel.

Shanta, V. \& Krishnamurthi, S. (1963) Further study in the aetiology of the carcinoma of the upper alimentary tract. British Journal of Cancer, 17, 8.

STERLING, G. \& ALFADLI, A. (1981) Site of 1000 primary malignant neoplasms in Saudi Arabia. Postgraduate Doctor (Middle East), 4 258.

TEMPLeton, A.C. (1973) Cancer of the breast. In: Tumours in $a$ Tropical Country (Ed by Templeton, A.C.), chapter 5. Springer Verlag, Heidelberg.

Thein-Hlang, \& Thein-Maung-Myint, (1978) Risk factors of breast cancer in Burma. International Journal of Cancer, 21, 432

THORNTON, J.R. (1981) High colonic pH promotes colo-rectal cancer. Lancet, i, 1081.

Tulinius, H., Day, N.E., Johannesson, G., Bjarnason, O. \& GONZALES, M. (1978) Reproductive factors and risk for breast cancer in Iceland. International Journal of Cancer, 21, 724.

VAKIL, D.V. \& MORGAN, R.W. (1973) Etiology of breast cancer. II Epidemiological aspects. Canadian Medican Association Journal, 109, 201.

WAINWRIGHT, J.M. (1931) A comparison of conditions associated with breast cancer in Great Britain and America. American Journal of Cancer, 15, 2610.

YUASA, S. \& MACMAHON, B. (1970) Lactation and reproductive history of breast cancer patients in Tokyo, Japan. Bulletin of the World Health Organisation, 42, 195. 